This item was submitted to Loughborough's Research Repository by the author.

Items in Figshare are protected by copyright, with all rights reserved, unless otherwise indicated.

\title{
Video documentaries in the assessment of human geography field courses
}

PLEASE CITE THE PUBLISHED VERSION

http://dx.doi.org/10.1080/03098265.2011.559578

\section{PUBLISHER}

(C) Taylor \& Francis

\section{VERSION}

AM (Accepted Manuscript)

\section{PUBLISHER STATEMENT}

This work is made available according to the conditions of the Creative Commons Attribution-NonCommercialNoDerivatives 4.0 International (CC BY-NC-ND 4.0) licence. Full details of this licence are available at: https://creativecommons.org/licenses/by-nc-nd/4.0/

\section{LICENCE}

CC BY-NC-ND 4.0

\section{REPOSITORY RECORD}

Mavroudi, Elizabeth, and Heike Jons. 2019. "Video Documentaries in the Assessment of Human Geography Field Courses". figshare. https://hdl.handle.net/2134/16192. 
Video documentaries in the assessment of human geography field courses Elizabeth Mavroudi and Heike Jöns

\section{Please cite this paper as follows:}

Mavroudi, E and Jöns, H (2011) Video documentaries in the assessment of human geography field courses, Journal of Geography in Higher Education, 35(4), pp.579598, ISSN: 0309-8265. DOI: $\underline{10.1080 / 03098265.2011 .559578}$

\section{Abstract}

This paper critically reviews the use of video documentaries in the assessment of human geography field courses. It aims to contribute to recent debates about the role of visual methods for developing active and deep learning in student-centred teaching. Based on four days of group work in Crete, 30 third-year students produced individual 10-minute video documentaries on 'Mediterranean Rural Spaces'. Analysing students' experiences of video production highlights the need for innovative teaching and assessment methods and the importance of creating independent and creative students equipped with a broad set of skills for an increasingly flexible job market.

\section{Key words}

video documentaries, students, human geography, field course, assessment, Greece 


\section{Introduction}

Visual methods have recently gained popularity in human geography research and teaching (e.g., Ansell, 2002; Rose, 2006, 2008; Latham \& Mccormack, 2007; Sanders, 2007; di Palma, 2009; Gandy, 2009). Based on the production and study of images such as photographs, videos, paintings and maps, this growing interest is closely linked to wider debates about the visual nature of the discipline (e.g., Rose, 2003; Matless et al., 2003; Dodge \& Perkins, 2008). For example, Cosgrove has highlighted the central role of the visual in geography, reminding us that "the visual also incorporates 'vision' and vision is much more than optical, it embraces the fact that seeing and picturing are as much acts of imagination as of perception" (Denis Cosgrove in Freytag \& Jöns, 2005, p.213).

This paper argues that using visual methods within teaching responds to a need for innovative teaching and assessment methods to create independent and creative students equipped with a broad set of skills for an increasingly flexible job market. However, despite the value of exploring the visual in geography, there has been less of a focus on the use of visual methods as forms of assessment in teaching (notable exceptions include Bullard et al., 2001: Latham and Mccormack, 2007: Wakefield and France, 2010). This paper adds to such debates by introducing the use of video documentaries in the assessment of a human geography undergraduate, third year field course module entitled 'Mediterranean Rural Spaces Field Course' that was conducted in Crete by the Department of Geography at Loughborough University. Conceived by Dr Elizabeth Mavroudi and run together with Dr Heike Jöns, a fellow lecturer, and Mr Mark Szegner, the departmental IT technician, this field course took place for the first time in the second semester of the academic year 2008/09. Based 
on group work in the field, the students were asked to produce an individual 10minute video documentary that accounted for $25 \%$ of the module mark. In this paper, we critically discuss the experiences, advantages and limitations of such assessment using feedback from the 30 students involved. The qualitative data for this paper was collected by analysing students' field journals and the module feedback forms they completed at the end of the semester. A close reading of these was conducted and any writing on video journals was coded, analysed and cited in an anonymised way based on an individual identification code for the 30 students ranging from $A A$ to $B D$.

The paper is divided into three parts. The first part contextualises the use of video documentaries as an assessment method in human geography field courses within recent efforts in the discipline to develop student-centred teaching that promotes active and deep learning. The second part outlines the structure and practicalities of the field course. The third part analyses students' experiences of producing a 10minute video documentary.

\section{Geography, active learning and visual methods}

Encouraging university students to reflect on the nature and politics of their geographical education, Castree (2005) discusses what students hope to gain from doing a geography degree, apart from a standard qualification. He stresses the importance of creative, analytical and discursive skills as well as of a questioning and inquisitive mind. Geography is an invaluable degree that teaches students important skills and knowledge relevant to the contemporary world but above all, it can teach students to think actively and imaginatively about current and future social and environmental challenges that require radical and holistic solutions. Therefore, 
as geography lecturers we need to develop teaching and assessment techniques that respond to this and that encourage active learning. This requires an emphasis on student-centred teaching and the consideration of students' very different learning styles (Fry et al., 2003).

\section{Active and deep learning}

Active learning creates many benefits for both students and lecturers. Such benefits include the facilitation of higher order thinking skills such as analysis and evaluation (Bloom et al., 1984). This means that students have to actively engage with material in a sustained way by 'doing' rather than by passively receiving information. As Gibbs (1988, p.9) suggests: "It is not enough just to do, and neither is it enough just to think. Nor is it enough to simply do and think. Learning from experience must involve linking the doing and the thinking." Active learning or learning by doing is more likely to encourage students to adopt a deep approach to learning than is the transmission model, which may encourage a surface approach (Prosser \& Trigwell, 1999). However, activity on its own, of course, does not bring about learning; it needs to be integrated with critical thinking, which Johnston (2003) argues is the key purpose of university-level education, and with reflection upon the doing (Scheyvens et al., 2008). Drawing upon Toohey's (1999) generic model of learning in five stages, Scheyvens et al. (2008) argue that the last three stages are often ignored by lecturers: (1) be introduced to topic; (2) get to know it; (3) try it out; (4) get feedback; (5) reflect and adjust. It is thus important to encourage students to reflect and to provide them with as much continuous feedback as possible. 
There are many strategies for encouraging deep learning by the way in which a module is taught and assessed. For example, lectures can be broken into different segments in order to enhance student-centred learning (Bligh, 1972; Horgan, 2003). Within geography, the suggested methods for making lectures more interactive reflect the varied content of the discipline (Gibbs et al., 1992; Charman \& Fullerton, 1995; Healey \& Roberts, 2004). Student-focused approaches are not only recommended as a way to encourage a deep approach to learning (Wenger, 1998, cited in Hockings, 2005; Gosling, 2003) but, as a study by Hativa \& Birenbaum (2000, cited in Norton et al., 2005, p.538) reiterates, students do in fact prefer such student-centred approaches. Most importantly, this means that students are not only supported in learning but that they should take responsibility for their own learning (Hockings, 2005). They should be enabled to "possess a capacity to look at problems from a number of different perspectives, to analyse, gather evidence, synthesize, and be flexible, creative thinkers" (Aulich, 1990, cited in Carnell, 2007, p.27). By outlining the concept of inquiry-based learning (IBL), Sponken-Smith et al. (2008, p.85) explicitly promote "a philosophical approach to teaching that is questiondriven, and involves active, student-centred learning. The role of the teacher is one of a facilitator or mentor, who seeks to guide the students through the inquiry process". Deep learning can also be seen as synonymous with reflection and selfassessment where students are continuously aware of their own learning and abilities (Castree, 2005). Finally, a variation of assessments in the form of exams, essays, oral presentations, websites, field journals, problem-solving exercises and the like can also encourage students to think more critically about the material they are exploring and learning. 


\section{Geography field courses}

In this paper, we focus on the implementation of video documentaries as an assessment method in human geography field courses to encourage active and deep learning in student-centred teaching. Geography field courses are regarded as an important aspect of geography degrees (Kent et al., 1997). In particular, they have been seen as a way to encourage active thinking, deep learning, critical reflection as well as problem solving 'in the field' (Connell, 2006). However, according to May (1999), there has been less attention paid to how social and cultural geographers - as compared to physical geographers - use field trips. Highlighting the need for human geographers to conduct specialised residential field trips, he acknowledges concerns such as those given by Rose (1993) who questions the value of traditional residential field classes in learning critical human geography because of the dangers of exoticising the unfamiliar when emphasis is given to 'expert' knowledge and the damaging influence of masculinist culture. Therefore, May (1999) suggests making the research fieldwork process more reflective and stresses the need to take positionality and the relationships between researcher and researched into consideration when designing undergraduate social and cultural geography field courses. Based on a ten day field trip to Las Vegas and Los Angeles, May (1999) illustrates some of the ways in which such field courses can examine key issues within the sub-discipline such as the politics of place and positionality as well as multiple and competing voices, representations and forms of knowledge (see also Katz, 1994; Rose, 1997; Pratt, 2000; Nairn, 2005).

Despite potential shortcomings, Hope (2009) recently highlighted the value of field trips because of the direct experience that students get and that can often change 
their opinion about other people and places. The key appears to be setting up field trip situations whereby students are able to engage and interact with local people and the issues they face, rather than being outside observers. Putting students outside their comfort zone can also bring to the fore surprising creativities and thought processes. In this way, designing a field trip in which students do things they would not normally do can heighten their sense of perception, curiosity and awareness.

\section{Visual methods in teaching}

The use of video documentaries as a form of assessment can help in this endeavour. Such assessment has not been greatly discussed in the literature. While there has been some writing on its value to school children (di Palma, 2009), and the

use of audio and video podcasting across different disciplines (Salmon \& Edirisingha, 2008), the discussion of creating videos has mainly focused on research (e.g., Banks, 2001; Rose, 2006; Pink, 2007; Gandy, 2009). An exception is the article by France and Wakefield (2010) on implementing digital stories in the assessment of a first year module entitled 'Foundations for Successful Studentship' with c. 70 students per year. The authors argue that students entering higher education are increasingly equipped with technological skills that pave the way for using digital technologies in the assessment of teaching. Their findings on students' perceptions through a pre and a post digital story questionnaire highlight students' confidence and competency with digital technologies, while they felt a nervousness about filming and creating the audio voice over track before the field experience took place. 
It is perhaps surprising that geographers have not published more extensively about using video documentaries for assessment purposes, which might reflect that they are not widely implemented. One reason for this may be the ethical implications that can arise in the filming and representation of Others. In this paper, we argue that this messy positionality and the representational and ethical challenges of filming can teach students about two things: first, the complexities of speaking for others; and second, the importance of letting subjects and environmental settings to have a 'voice'.

Using visual material such as film and digital photographs in the assessment of field trips can also keep students interested and help them learn about representations (Ansell, 2002; Latham \& Mccormack, 2007). Sanders highlights the significant learning effect resulting from enabling students to 'see' geography for themselves through the use of visual material in geography teaching:

First, they develop an appreciation for looking and seeing and accordingly recognize that they are active endeavours-not passive ... A challenge for teachers of upper-level courses is to move beyond mere definitions and meanings of concepts to the point where students come to appreciate geography as multidimensional, integrated and performative. Seeing geography's 'realness' is enormously valuable (2007, p.188, 192).

Asking students to engage in field work using visual methods such as photographs and video documentaries can also help encourage them to question and explore differing and often contested representations (Sidaway, 2002; Mains, 2004), which 
are at the heart of geographical practice (Radcliffe, 1994; Robinson, 1995) and thus have played an important role in geography teaching as well (Gilmartin, 2004).

By getting students to construct their own video documentary, we were aiming to develop their ways of 'seeing' and 'representing' geography in order to expand their own imaginations of Crete and to further their organizational, communication, critical and reflective skills. In the remainder of this paper, we will introduce the context of the field course to Crete and examine to what extent these aims were achieved from the perspective of the students' reflections and feedback.

\section{Background and practicalities of the field course}

The third year undergraduate module 'Mediterranean Rural Spaces Field Course' was developed to help widen the department's module provision in rural geography and to create a new thematic based field course. In order to ensure that the module was interesting and relevant, it was made as diverse and broad as possible. Apart from the normal challenges of setting up a field course, the assessment demanded particular consideration. Methods already used by the department included field journals and website creation (Bullard et al., 2001). Therefore, it was felt that a new method of assessment was needed, one that would encourage students to be creative, learn a new skill and allow them to interact not only with space and place but also with each other in potentially more meaningful and interesting ways than they would do with more conventional methods of assessment that constituted most of their undergraduate work (e.g., coursework essays). Eventually, three assessment methods were chosen that linked the field experience to the four introductory lectures of the field course. Each student had to compile an in-depth field journal 
( $25 \%$ of the module mark), write a theoretically based 5 -page essay $(50 \%$ of the module mark) and create an individual 10-minute video documentary based on group work in the field ( $25 \%$ of the module mark). Both the field journal and the video documentary constituted forms of assessment the students had not encountered in a human geography field course before.

The field course took place in Central Crete at the end of April 2009 and lasted six days (Figure 1). Although most of the teaching was done in situ, four 50 -minute lectures were delivered prior to going to Crete in order to provide the students with background material on an island most had never visited before. In order to help to structure the module, the material was divided into four main topics, namely 'Landscape, History and Heritage'; 'Agriculture and the Rural Environment'; 'Spaces of Tourism'; and 'Migration and Identity'. The material was meant to cover the main issues relating to rural spaces in Crete, using Central Crete as an in-depth case study. During the lectures, these topics and concepts such as heritage tourism and agro-tourism were linked to places that we were going to visit during the field course so that the students could get a sense of the itinerary, and of our rationale for including certain sites, walks, and appointments with local experts. The intention was also for the students to experience a different Crete to the one they had heard about (e.g., clubbing in Malia) and to critique stereotypes and assumptions about the island and its people. Therefore, we were based in the rural environment of Arolithos, a hotel designed in the form of a 'traditional' Cretan village. We also included two guided walks. The first guided walk was led by a local British expatriate, Anne Bouras, who took us to an area of the Lasithi Plateau. She talked to the students about Cretan life, landscapes and villages, and provided valuable insights into her 
own life as a migrant. The second guided walk was led by Dr Babbis Fassoulas, Vice president of the Management Committee for the Psiloritis Natural Park, a European and UNESCO Global Geopark. Dr Fassoulas showed us the geological and cultural heritage along one of the newly established alternative tourist trails in the high mountains of the Psiloritis Geopark, namely the Migia trail near Anogia. Mavroudi's own experiences of Crete also helped to provide the students with autobiographical insights on Greek culture as she is half Greek, grew up in Greece and has been to Crete many times.

\section{[Please insert Figure 1 about here]}

The teaching also included two practical sessions with laptops and video cameras, 50 minutes before the field trip and 100 minutes after. The pre-field trip practical was to show the students how to use the video camera in the field, as well as to convey the basics of video-editing. The post-field trip practical offered detailed guidance and advice to students on the technical and academic aspects of video-editing in relation to material they had collected in the field. There were 15 students per group in the first practical and eight students on average in the second one to ensure as much individual attention as possible. Both practicals were taught by Mark Szegner, the departmental IT technician, while Mavroudi and Jöns provided advice on the content of the video documentaries. Students were told that they could focus on any of the four module topics for the video documentary to ensure as much flexibility as possible (Figure 2). In the field, the students worked in five groups of four students and two groups of five students. They had access to one video camera and one laptop per group. As each student was asked to produce an individual 10-minute 
video documentary based on the footage taken by the group in the field, the three main tasks after the field trip were to select the appropriate video material, to write a relevant voice over that critically discussed the video footage, and to coordinate images, audio track and voice over in the video editing process.

[Please insert Figure 2 about here]

The implementation of video documentaries as an assessment component represented an innovative way of incorporating new technology into Geography teaching at Loughborough. The department owned ten Sony DCR-HC Handycams that were available for students, but which were underutilised so the field trip provided an excellent way to use this equipment. In order to do so, new laptops were needed that were equipped with the appropriate video editing and production software so that the students could download and view the collected data as well as begin with the video editing process whilst in the field. Mark Szegner, the IT technician, used departmental and faculty funds to set up ten Apple Macbooks Pro with the operating system Mac OSX and the video software Apple iMovie $H D(6)$ in order to guarantee a smooth operation of the laptops when working with large video files. iMovie HD is a functional and user-friendly software that enables a relatively straightforward editing and coordination of moving and still images and different audio tracks. In our case students needed to coordinate those audio tracks produced whilst filming in Crete (in situ) and when back in Loughborough (voice over). Mark Szegner provided invaluable support during the trip and helped students with any technical issues, thus helping to reduce technological hurdles for the students. We were also asked to come up with strict ethical and health and safety guidelines to guide students in their field work using cameras (Figure 3). All guidelines were 
approved by the University Ethics Committee and by the Departmental Learning and Teaching Committee.

[Please insert Figure 3 about here]

\section{Video documentaries as a form of assessment: experiences, advantages and limitations}

A key aim of the video documentary was to get the students to engage with how and why Cretan rural spaces have been changing. By pursuing this wider topic, the students had a certain degree of flexibility in terms of what topic to focus upon as the literature suggests that flexible, adaptive teaching is a particularly effective approach (Dunkins \& Precians, 1992, cited in Norton et al., 2005; see also Figure 2). This implies that the lecturers have to remain open to change and suggestions by students in order to assess what works best in particular contexts and for particular individuals. For example, one of the best video documentaries successfully focussed on the question of sustainability across three of the field course's four main topics as this student was about to do a Masters degree in Sustainability Research and thus wished to follow her particular interest. However, there was less flexibility in terms of where the students could film as there was a quite tight itinerary and the whole group was taken by coach from one place to the next (see Figure 1 and discussion below). Based on the analysis of students' reflections in field journals and module feedback forms, we identified five key areas that will be discussed in the following order: positionality of the filming students; deep learning; ethics and engagement; technical practicalities; time constraints and group dynamics. 


\section{Positionality}

Students were encouraged to be aware of differing representations of rural Crete, to engage with as many people as possible, and to be reflexive, self-aware and sensitive in their observations. The value of the group work for taking video footage is underlined by the following student's highly reflective observation on the fact that different people 'see' and 'represent' the same places in quite distinct ways:

The idea of the video documentary really gave the field trip a different slant and it was interesting watching back the day's footage in the evening - what people see is all so different and although being in the same place other members of your group capture aspects you often missed yourself. (Student AV)

The students' strong visibility with video cameras in rural areas made them think about how they were representing others and how they were perceived and represented by Cretans. By making the group highly visible, the video project forced the students to ask questions about how to represent the power relations and difficulties involved as well as about their own positionality, i.e., how they fitted into the rural spaces they encountered:

In terms of filming Malia, to show what it is like is very difficult to do when out of peak season as the town is dead, however coming in peak season in such a large group would be highly impractical as it does make representing the space as it is going to be put in the video difficult. (Student AF) 


\section{Deep learning}

The movement of filming was also important as it highlighted to students the mobility and dynamics of the world in which they live; rather than rely on photographic snapshots, students were actively placing themselves in spaces that were constantly changing and to which they had to adapt to and make sense of. As such they were performing the field trip as they filmed what they saw and did, and as a result they actively engaged with their surroundings rather than relying solely on their lecturers to tell them about the places they visited. Some students highlighted that taking the video footage helped them to appreciate and make sense of their new surroundings and thus encouraged a certain form of deep learning:

The filmmaking has made the day more interesting. It enables us to focus in on particular topics engaging in stronger opinions and a better understanding compared to just note-taking. (Student BA)

By using the video camera for exploring different sites in Central Crete, students seemed to be very attentive to detail that they might have overlooked otherwise:

In order to gain material for our video documentary on tourism it was interesting to film the signs in the old town (of Malia) - mostly in Greek - and those on the 'beach road' which were nearly all in English. (Student AG)

They also actively engaged in planning their video documentary by thinking about the upcoming field days, taking responsibility for their own learning and critically reflecting about the topics in relation to place: 
Visiting an example of agro-tourism will be especially useful for my video documentary as I intend to focus on the sustainability of tourism and its future. (Student BB)

\section{Ethics and engagement}

The field journals also revealed how students used the video cameras to connect with local people and how it made them think about the ethics of filming and representation:

At Malia we needed to be much more careful to prevent filming children or people's faces. The interview with the hotel manager was successful. We balanced the camera on a worktop to keep the camera perfectly steady. The sound quality was good because we were fortunate enough to be able to film in his private office. The man was a great help. ... Due to the lack of light in the cave, the shots were not brilliant. Also, I was disappointed that I could not formally interview the tour guide operators I had met; this was due to their companies' policies against being filmed. (Student AJ)

The avoidance of filming children and inappropriately dressed individuals on the beach emerged as one of the main ethical issues to be negotiated by the filming students:

At Matala whilst filming the beach a French couple were looking at us strangely thinking we were filming their child who was playing in the sea. Also when 
taking panoramic shots out into the bay we tried to avoid getting topless sunbathers in our video footage. (Student Al)

Altogether, students' engagement with locals and tourists was based on a confident use of informed consent forms:

Margarites was the perfect opportunity to film traditional aspects of Crete. I also did some good voice over in our video documentary in Margarites. We saw a woman walking in her garden and showed her the informed consent form to sign so that she was aware that she was participating in a video documentary exploring rural spaces in Crete. (Student Al)

In fact, it can be argued that the need for filming encouraged the students to talk to tourists and locals. Even though language was sometimes an issue, certainly in tourist areas, many interviewees did speak English:

In filming the visit to the farm, my group took care to film the tour so that we could later refer back to the success of it; we also interviewed the guide in order to gain more insight into the farm and the types of tourists that visited so that we could draw conclusions on different types of tourists and tourist spaces within Crete. (Student AL)

However, there were also limitations for the engagement with Cretan life as some of the walks in remote areas did not allow for close interactions with locals because of time constraints and language barriers. Instead, the video coverage was sometimes 
superficial, distanced and almost panoramic in nature with an emphasis on the nonhuman aspects of environments:

Although the information provided by Mrs Bouras was very interesting and insightful, in shooting footage for the documentary, I was only really able to record images of the physical nature of the villages and their remoteness - the inability to communicate with the villagers and the 'behind the scenes' nature of much of the conducted work ...meant it was difficult to ascertain a 'human's' account of what was happening instead relaying on numerous panning shots of landscapes, animals and architecture. (Student AO)

\section{Technical practicalities}

The field journals contained numerous references to the practicalities of filming. While some groups struggled to get to grips with using the camera in the field and thus did not obtain as much footage as they wished during the first stop at Knossos, most students were pleased and even surprised by the results on the first day:

The camera work was on the whole successful at this site (Knossos). I managed to develop a good technique for keeping the camera steady and really enjoyed finding creative, professional and pleasing shots to the eye. I found that using the zoom very gently and extremely slowly produced professional shots. I was happy with the first day of filming. I managed to capture several important shots such as the long queues to enter certain rooms and the large groups of tourists which surrounded single tour guides. (Student AJ) 
The technical challenge of this new skill was in fact much less significant than both the students and module tutors had anticipated, which resonates with the argument by Wakefield and France (2010, p.1) about students being more "technological capable than ever before":

The fieldwork we carried out for the most part went well, once we had got to grips with the camera and the concepts we wanted to highlight for our documentary ... we found it easier than we thought to each get the footage we wanted, when we loaded the footage onto the computer, we were all pleased with the material we gathered on the first day. (Student AM)

The largely positive experience did not only relate to using the camera in the field but also to the editing process back in Loughborough:

I really liked the video aspect of the module, during the field trip and editing it. I thought I wouldn't enjoy the editing but liked doing it - different from essays etc, that we normally do. Made the module more interesting adding this element. (Student BA, feedback form)

However, not all of the sites visited provided a suitable environment for filming, particularly when it was windy along the coast: 
Amnissos: The largest issue was on the beachfront; the wind made recording audio almost impossible. Again keeping the camera steady was an issue especially while walking on the beach. (Student AJ)

The main practical problems encountered during filming, particularly at the beginning, related to sound quality, keeping the camera steady, focusing on the image, and zooming in and out too fast and/or too abrupt. Students' suggestions for improvement included supplying Tripods in the future to avoid some of the shaky footage and to do more practical training in camera usage before the start of the first field day. However, students clearly increased their confidence in relation to filming towards the end of the fieldtrip, thus fully enjoying the experience and taking some of their best shots:

In terms of video documentary for the day I thought we took some excellent footage at Gortyn - especially of the church of St Titus. When walking from the car park at Phaistos to the ruins we took some really good panoramic shots across the Messara Valley. (Student Al)

\section{Time constraints and group dynamics}

Time constraints and group dynamics were another important topic addressed in the field journals. Students in one group often followed different thematic interests. On the one hand, this meant that the camera passed between group members at different sites, leaving sufficient time for individuals to gain the footage for their individual documentary, but on the other hand, the tight schedule sometimes did not allow an as in-depth coverage as the students had hoped for: 
Lasithi: we managed to film some of the dis-used windmills from a distance, however, I would have liked to see them closer and learn more about them considering they are one of the cultural, historical images of Crete...we tried to capture on film the traditional villages, farm tracks - to provide a contrast to the agro-tourism farm tomorrow. Difficult to film and keep up with the tour group end up at back of group, quite a long day, not as much footage as we would have liked. (Student AY)

The time constraints were unfortunate in some ways because students were unable to re-visit places and sometimes felt they did not have enough time to film or interact with locals but on the other hand, this was the only way to cover a variety of sites relevant to a range of different topics and thus to attend to different student interests. Unforeseen delays such as a much longer presentation by the deputy mayor of Malia contributed to insufficient time for taking video footage in some places such as Malia. Students' reflections on these problems underline that they actively discussed the process of taking video footage in the field, and that they constantly engaged with their surroundings in order to evaluate their progress in relation to their final piece of assessment.

\section{Reflection and evaluation}

Overall, the experience of filming was a positive one that not only encouraged active and deep learning, creative thinking and critical reflection but also enabled students to acquire a new set of technical and academic skills. Even though the students had one session with the video camera before they went, there was quite a steep 
learning curve for them when they got to Crete. With hindsight, they should probably have practiced with the video camera on the first afternoon we were there before we started the fieldwork properly. Such a practice session on the first field day worked well in the production of digital stories discussed by Wakefield and France (2010) as students appreciated the opportunity to produce a practice digital story before doing the assessed version. Module feedback forms provided us with further proof that some students felt they needed more practice and guidance before filming in the field, but there were no major issues when it came to video editing and production back in Loughborough.

According to Wakeford (2003, p.42), the assessment of student learning is not well understood. However, he stresses the need for assessment to be accurate, and highlights that it is an integral part of student learning. Having clear and wellformulated marking criteria is therefore very important and in fact a requirement for assessing work in the Department of Geography at Loughborough University. As the Department had not assessed video documentaries before, we had to write a new set of marking criteria that was made available to all students at the start of the module (Figure 4). These marking criteria stress that we were assessing students' ability to create an informative video documentary based on original material (video taken in the field, still images and own commentary). We looked for a clear structure (i.e. an introduction, a main part and a conclusion), for relevant images, interviews and comments by the students, for a flow of the commentary, and for an argument that critically reflected on the chosen topic and showed signs of creativity and originality. Ideally, the material presented in the video documentary went beyond the information provided in the module lectures, thus showing evidence of active 
learning in the field and independent research back at home. Engagement with the human and physical aspects of rural space through the video footage and the commentary was as important as reflection about relevant details and students' changing positionality when moving through the Cretan landscape. Although we did not expect students to cite academic literature in their voice over, we encouraged wide reading beyond the module reading list in order to strengthen both commentary and overall argument. The emphasis was therefore on assessing the content of the video documentary but we did also take into consideration the quality of the video and audio material and the length of the documentary.

The marking of the 30 individual 10-minute video documentaries occurred over the space of two half days, and we assigned 15-20 minutes per video. All three members of staff watched the videos together, made notes and then discussed and agreed upon the final mark. The marking criteria were used as a guideline to ensure marking was as fair as possible. The final marks for the documentaries ranged from $58 \%$ to $87 \%$ with an average mark of $69 \%$ (the range of marks is $0 \%$ for no or late submission to $100 \%$ but on this scale only 20 different marks that are defined in the marking criteria can be granted). This was a high average mark that reflected the considerable amount of videoing, research, creativity and technical skill invested by the students and contributed to the very high average module mark of $69.3 \%$ (field journals: $73 \%$; academic essays: $66 \%)$.

We decided that in the future students would need a little more guidance in terms of how many still photographs and sub-titles they could include as well as the importance of structure. For example, a number of students had forgotten to 
introduce their documentary in the voice over. One of the major limitations raised by the students was the fact that they only had one week with the laptops when they returned; while this did not seem to impact upon the quality of their presentation, it did mean that they had to work quickly and intensively which may have helped them to focus on the job in hand. We were not able to show the video documentaries to the class as the hand-in deadline had to be in the final week of the semester but the students received in-depth written feedback on their individual piece of work, and we will consider making a selection of the best videos available online.

[Please insert Figure 4 about here]

\section{Conclusions}

With a view of applying student-centred teaching to a new human geography field course in Central Crete that would encourage active and deep learning, this paper has discussed students' experiences with producing individual 10-minute video documentaries based on four days of group work in the field. Analyzing the students' reflections on the process of video filming and editing as documented in their field journals and module feedback forms, we have highlighted five key areas of student learning in the field: (1) positionality; (2) deep learning; (3) ethics of filming and engagement; (4) technical practicalities of filming; (5) time constraints and group dynamics.

The analysis illustrated that the use of video documentaries as a form of assessment allowed the students to learn a new and interesting skill, and to be creative, both in the field and when putting together their final piece of assessment in Loughborough. 
The video documentaries formed an important aspect of the module and succeeded in developing students' ways of 'seeing', 'representing' and 'imagining' different aspects of rural Crete. This, together with their reflective field journals, kept students interested and attentive throughout the field days, encouraged active and deep learning about a second specific topic (besides the academic essay), and also added to the organizational, critical and reflective skills as well as technological and transferable skills that students gained at Loughborough University. Implementing video documentaries as a new assessment method thus equipped the students with a broad set of skills important for their employability and future success in an increasingly flexible job market.

We got very little negative feedback on the module feedback forms and were pleased with what the students achieved. All students seemed to enjoy themselves, which we also feel is important for a successful field course experience. Learning can be fun, thought-provoking and inspiring. Wright (2005) stresses that students want lecturers who are 'human' and he feels that it is "said that our students see some of us as something perhaps different from what they want; someone they can connect to, learn with and be inspired by" (ibid, p.7). Marten (2005) has also commented that students want lecturers that they can engage with and who are approachable. If students feel at ease with us as module tutors, they may be more likely to engage with the module and to try and excel and we feel that this occurred in Crete based on the close everyday interaction and ongoing feedback provided on the technical and academic aspects of video filming.

Students used filming to help them connect with the changing spaces they moved through and to analyse the different places they were experiencing. Part of our 
rationale for the fieldtrip was to get them to appreciate differing representations and approaches to Crete and to challenge any pre-conceptions they had both of Crete and of rural spaces. We wanted them to think critically about where they were, about the problems and opportunities of certain areas and that people faced, and the range of topics chosen for the video documentaries clearly proved that this was the case. In the process, teaching itself can become a transformative process, in which there is a commitment to creating social change (Wellens et al., 2006) as well as individuals who are well-equipped to lead and shape the world of the future.

Compared to other methods of assessment such as coursework essays, the use of video documentaries for the assessment of student learning seems to have many advantages. Producing a video documentary appeared to allow students to engage more deeply with rural Crete and to develop and illustrate critical thinking skills as they were constantly looking out for new relevant video footage when being in the field. We realised that students were thinking independently and engaging closely with their environment through reading their reflections on the video filming process in their field journals. There was evidence of active learning as students had to take responsibility for their video projects and decide how to structure them and what to include. Through the requirement of editing the video footage and producing a voice over back in Loughborough, the dimensions of 'doing' and 'thinking', as demanded by Gibbs (1988), were in fact closely intertwined at all stages of producing this assessment. Critical reflection was necessary for evaluating the usefulness of video images and for producing an informative commentary. The combination of filming, editing and commenting actually enabled us as module tutors to closely monitor all five stages of student learning as discussed by Scheyvens et al. (2008). We were 
able to judge students' academic and technical knowledge acquired in the module lectures and practicals and during the field trip (stages 1 and 2); their awareness of and reflection about gathering relevant and useful visual material in the field (stage 3); their willingness to receive our feedback in the field and in the post field trip practical (stage 4); and their ability to respond to this feedback when compiling the final video documentary (stage 5).

In comparison to oral presentations, we noticed that the individual personality of the student was much less noticeable in the video documentaries as this only featured their voice in the commentary but not necessarily their body language or the way they dressed as they did not need to appear in the documentaries themselves. For students that are less comfortable with presenting, this reduced visibility is clearly an advantage as the content conveyed by images and voice gains more prominence. Also, students could record the commentary several times until they were satisfied with their audio performance. Overall, we consider video documentaries as a very useful assessment method that supports the development of undergraduate students as critical thinkers and deep learners by encouraging them to engage with space and place in ways they would not have previously done.

There are also limitations of all assessment methods. For example, insider-outsider relationships will always exist in the field work process as students negotiate issues of representation, ethics and positionality. From our perspective, the two main disadvantages of video documentaries more specifically are the technical requirements and the difficulty to detect plagiarism in the commentary. There are certain factors that we can improve upon such as time constraints and more practice 
with the video cameras beforehand but we were very pleased with the module, particularly as the technical support during the time in Crete guaranteed a smooth running of the filming process. We have found that, on the whole, a mixed assessment approach, incorporating an academic essay, field journal and video documentary works extremely well to stimulate students' interest and critical thinking. In conclusion, this field course module proved to us that taking a risk, doing things differently and emphasizing visual methodologies in geography teaching can pay off for both students and teachers.

\section{Acknowledgements}

We would like to thank all the students who participated in the field course as well as Mark Szegner for his expert technical help and advice. We are also grateful to the editor Craig Jeffrey, two anonymous referees, and Kelly Wakefield for providing excellent comments that helped to improve the final version of this text.

\section{References}

Ansell, N. (2002) Using films in teaching about Africa, Journal of Geography in Higher Education, 26(3), pp. 355-368.

Banks, M. (2001) Visual Methods in Social Research (London: Sage).

Bligh, D. (1972) What's the Use of Lectures? (Harmondsworth: Penguin).

Bloom, B. S., Krathwohl, D. R. \& Masia, B. B. (1984) Taxonomy of Educational Objectives: The Classification of Educational Goals (New York: Longman).

Bullard, J., Hubbard, P. \& Dalgleish, H. (2001) Producing web pages for assessment, Journal of Geography in Higher Education, 25(3), pp. 395-403. 
Carnell, C. (2007) Conceptions of effective teaching in higher education: extending the boundaries, Teaching in Higher Education, 12(1), pp. 25-40.

Castree, N. (2005) Whose geography? Education as politics, in: N. Castree, A. Rogers \& D. Sherman (Eds) Questioning Geography, pp. 294-307 (London: Blackwell).

Charman, D.J. \& Fullerton, H. (1995) Interactive lectures: a case study in a geographical concepts course, Journal of Geography in Higher Education, 19(1), pp. 57-68.

Connell, J. (2006) 'I can't eat that, it's purple': a geography field course in Vanuatu and Fiji, Geographical Research, 44(1), pp. 17-27.

di Palma, M. T. (2009) Teaching geography using films: a proposal, Journal of Geography, 108(2), pp. 47-56.

Dodge, M. \& Perkins, C. (2008) Reclaiming the map: British geography and ambivalent cartographic practice, Environment and Planning A, 40(6), pp. $1271-1276$

Wakefield, K. and France, D. (2010) Bringing digital stories into assessment, Planet, in press

Fry, J., Ketteridge, S. \& Marshall, S. (2003) Understanding student learning, in: H. Fry, S. Ketteridge \& S. Marshall (Eds) A Handbook for Teaching \& Learning in Higher Education: Enhancing Academic Practice, $2^{\text {nd }}$ edition, pp. 9-25 (London: RoutledgeFalmer).

Freytag, T. \& Jöns, H. (2005) Vision and the cultural in geography: a biographical interview with Denis Cosgrove, Die Erde, 136(3), pp. 205-216.

Gandy, M. (2009) Liquid city: reflections on making a film, Cultural Geographies, 16(3), pp. 403-408. 
Gibbs, G. (1988) Learning by Doing: A Guide to Teaching and Learning Methods (London: Further Education Unit).

Gibbs, G., Habeshaw, S. \& Habeshaw, T. (1992) 53 Interesting Things to Do in Your Lectures, $4^{\text {th }}$ edition (Bristol: Technical and Educational Services Ltd.).

Gilmartin, M. (2004) Geography and representation, Journal of Geography in Higher Education, 28(2), pp. 281-284.

Gosling, D. (2003) Supporting student learning, in: H. Fry, S. Ketteridge \& S. Marshall (Eds) $A$ Handbook for Teaching and Learning in Higher Education, $2^{\text {nd }}$ edition, pp. 162-182 (London: RoutledgeFalmer).

Healey, M. \& Roberts, J. (Eds) (2004) Engaging Students in Active Learning: Case Studies in Geography, Environment and Related Disciplines (Cheltenham: Geography Discipline Network).

Hockings, C. (2005) Removing the barriers? A study of the conditions affecting teaching innovation, Teaching in Higher Education, 10(3), pp. 313-326.

Hope, M. (2009) The importance of direct experience: a philosophical defence of fieldwork in human geography, Journal of Geography in Higher Education, 33(2), pp. 169-182.

Horgan, J. (2003) Lecturing for learning, in: H. Fry, S. Ketteridge \& S. Marshall (Eds) A Handbook for Teaching \& Learning in Higher Education: Enhancing Academic Practice, $2^{\text {nd }}$ edition, pp. 75-90 (London: RoutledgeFalmer).

Johnston, R. J. (2003) Response to Healey et al. Available at http://www.gees.ac.uk/linktr/linktr.htm\#ltringees (accessed February 2010).

Katz, C. (1994) Playing the field questions of fieldwork in geography, Professional Geographer, 46(1), pp. 67-72. 
Kent, M., Gilbertson, D. \& Hunt, C. (1997) Fieldwork in geography teaching: a critical review of the literature and approaches, Journal of Geography in Higher Education, 21(3), pp. 313-411.

Latham, A. \& Mccormack, D. P. (2007) Digital photography and web-based assignments in an urban field course: snapshots from Berlin, Journal of Geography in Higher Education, 31(2), pp. 241-256.

Mains, S. P. (2004) Teaching transnationalism in the Caribbean: toward an understanding of representation and neo-colonialism in human geography, Journal of Geography in Higher Education, 28(2), pp. 317-332.

Marten, R. (2005) What makes the best lecturer in geography, earth or environmental sciences, Planet, 15, p. 9.

Matless, D., Driver, F., Ryan, J.R. \& Crang, M. (2003) Intervention roundtable: geographical knowledge and visual practices, Antipode, 35, pp. 212-243.

May, J. (1999) Developing fieldwork in social and cultural geography: illustrations from a residential field class in Los Angeles and Las Vegas, Journal of Geography in Higher Education, 23 (2), pp. 207-225.

Nairn, K. (2005) The problems of utilizing 'direct experience' in geography education, Journal of Geography in Higher Education, 29(2), pp. 293-309.

Norton, L., Richardson, J., Hartley, J., Newstead, S. \& Mayes, J. (2005) Teachers' beliefs and intentions concerning teaching in higher education, Higher Education, 50, pp. 537-571.

Pink, S. (2007) Doing Visual Ethnography: Images, Media and Representation in Research, $2^{\text {nd }}$ edition (London: Sage).

Pratt, G. (2000) Research performances, Environment and Planning D: Society and Space, 18, pp. 639-651. 
Prosser, M. \& Trigwell, K. (1999) Understanding Learning and Teaching: The Experience of Higher Education (Buckingham: Open University Press/SRHE).

Rose, G. (1993) Feminism and Geography: The Limits of Geographical Knowledge (Cambridge: Polity Press).

Rose, G. (1997) Situating knowledges: positionality, reflexivities and other tactics, Progress in Human Geography, 21(3), pp. 305-320.

Rose, G. (2003) Just how, exactly, is geography visual? Antipode, 35(2), pp. 212221.

Rose, G. (2006) Visual Methodologies: An Introduction to the Interpretation of Visual Methods, $2^{\text {nd }}$ edition (London: Sage).

Rose, G. (2008) Using photographs as illustrations in human geography, Journal of Geography in Higher Education, 32(1), pp. 151-160.

Robinson, J. (1995) White women researching/representing "Others": from antiapartheid to postcolonialism?, in: A. Blunt \& G. Rose (Eds) Writing Women and Space: Colonial and Postcolonial Geographies (London: Guildford Press).

Radcliffe, S. (1994) (Representing) post-Colonial women: authority, difference and feminisms, Area, 26(1), pp. 25-32.

Salmon, G. \& Edirisingha, P. (Eds) (2008) Podcasting for Learning in Universities (Maidenhead: Open University Press).

Sanders, R. (2007) Developing geographers through photography: enlarging concepts, Journal of Geography in Higher Education, 31(1), pp. 181-195.

Scheyvens, R., Griffin, A. L., Jocoy, C. L., Liu, Y. \& Bradford, M. (2008) Experimenting with active learning in geography: dispelling the myths that perpetuate resistance, Journal of Geography in Higher Education, 32(1), pp. 51-69. 
Sidaway, J. (2002) Photography as geographical fieldwork, Journal of Geography in Higher Education, 26(1), pp. 95-103.

Sponken-Smith, R., Bullard, J., Waverly, R., Roberts, C. \& Keiffer, A. (2008) Where might sand dunes be on Mars? Engaging students through inquiry-based learning in geography, Journal of Geography in Higher Education, 32(2), pp. 73-88.

Toohey, S. (1999) Designing Courses for Higher Education (Buckingham: Open University Press).

Wakeford, R. (2003) Principles of student assessment, in: H. Fry, S. Ketteridge \& S. Marshall (Eds) A Handbook for Teaching \& Learning in Higher Education: Enhancing Academic Practice, $2^{\text {nd }}$ edition, pp. 42-62 (London: RoutledgeFalmer).

Wellens, J., Berard, A., Chalkley, B., Chambers, B., Healey, R., Monk, J. \& Vender, J. (2006) Teaching geography for social transformation, Journal of Geography in Higher Education, 30(1), pp. 117-131. 


\section{Figures}

Figure 1 Fieldwork itinerary for the module 'Mediterranean Rural Spaces Field

Course - Central Crete' in the academic year 2008/09

Tuesday, $21^{\text {st }}$ April 2009

13.05 Arrival of plane from UK followed by coach transfer to Arolithos

$15.30 \quad$ Introductory/health and safety briefing

\section{Wednesday, $22^{\text {nd }}$ April 2009}

$9.30 \quad$ Start and supermarket stop

10.30 Arrival at Knossos and official tour of the palace

11.15 - 13.30 Video documentary (including tourist spaces outside the palace) and lunch at Knossos (students by themselves)

13.30 Leave Knossos, drive to Amnissos

$14.00-14.15$ Briefing on Amnissos

14.15 - 15.00 Video documentary in Amnissos (students by themselves)

$15.00 \quad$ Drive to Boutari Winery followed by briefing on Boutari Winery

$16.00-17.00$ Official tour at Boutari Winery

$18.00 \quad$ Arrival at Arolithos

$19.00-20.00 \quad$ Video editing/group work session

Thursday, $23^{\text {rd }}$ April 2009

$9.00 \quad$ Start and supermarket stop

$10.00-10.45$ Official appointment with deputy mayor of Malia council, Mr Anastasakis, on tourism

$10.45-12.30$ Video documentary in Malia (students by themselves)

12.30 - 13.30 Drive to Dikti Cave on Lassithi Plateau

13.30 - 15.30 Exploration of Dikti Cave for video documentary (students by themselves)

$15.30-17.30$ Guided tour through villages and surrounding area by Anne Bouras

18.00 - 19.00 Dinner with Anne Bouras in Magoulas village

20.30 Arrival at Arolithos

\section{Friday, $24^{\text {th }}$ April 2009}

$9.00 \quad$ Start and supermarket stop

$10.30-12.00$ Visit to Agreco farm, tour by Eva Marvakis

$12.00-14.00$ Drive through mountains via Margarites village

14.00 Meeting with Dr Babbis Fassoulas, Director of Psiloritis Geopark

16.00 Arrival at Migia trail, near Anogia for a short walk with Dr Babbis Fassoulas

18.00 Arrival at Arolithos

18.30 - 19.30 Video editing/group work session

\section{Saturday, $25^{\text {th }}$ April 2009}

$9.00 \quad$ Start and supermarket stop

$10.30 \quad$ Arrival at Gortyn followed by briefing on Gortyn

$10.45-11.15$ Exploration of Gortyn and video documentary (students by themselves)

$11.30 \quad$ Arrival at Phaistos followed by briefing on Phaistos

11.45 - 12.30 Exploration of Phaistos and video documentary (students by themselves)

13.00 Arrival at Matala followed by briefing on Matala

$13.15-15.00$ Video documentary at Matala (beach, caves, surroundings) and lunch (students by themselves)

15.15 Arrival at Kommos beach followed by briefing on Kommos

$15.30-16.00$ Video documentary at Kommos beach (students by themselves)

$16.00-16.15$ Agriculture in the Messara valley

$18.00 \quad$ Arrival at Arolithos

18.30 - 19.30 Video editing/group work

Sunday, $26^{\text {th }}$ April 2009

10.30

11.50
Checkout at Arolithos followed by coach transfer to the airport

Check-in at airport 
Figure 2 Selection from instructions given to students on the assessment

\author{
component 'video documentary'
}

The third assessment component will involve a video documentary with a detailed and informative oral commentary ( $25 \%$ of the module mark). When you are in Crete, you will be filming rural spaces using a video camera. You will be divided into groups and we will give you one camera per group. Therefore, you MUST take the camera in turns to film within your group so that everyone gets a chance to film. Please make sure that you adhere to the ethical code of conduct for filming which can be found in Appendix 1. We will also provide formative feedback on each video presentation in order to ensure that all ethical considerations are taken into account before the final production and submission of this piece of coursework. Although you will be working in groups in the field, this is an individual assignment and you will be video-editing and producing group-collected material on an individual basis. Therefore, you will each need to produce a documentary which will be roughly $\mathbf{1 0}$ minutes long. You will need to create audio material to go with the documentary. This should be both in situ audio material that was collected while filming (e.g. whilst talking to people or commenting on your experiences in the field) and voice over material that is created whilst editing and film production. The video can be on any of the topics outlined in the preparatory lectures. You are not limited to any particular theme so you can choose to focus on an overview of rural spaces in Crete or on a specific topic that interests you. Questions to help you structure and guide your presentations are included below.

\title{
Landscape, History and Heritage
}

- Document, explore and discuss important features and representations of the Cretan rural landscape.

- What are the effects of the history of Crete on the present landscape and its people?

- How has the rural landscape been changing over time and space?

- How is heritage constructed as part of Cretan rural life and identity?

- What are the relationships between heritage, landscape and tourism?

Agriculture and the Rural Environment

- Examine and discuss the different modes of agricultural production in Crete.

- Where does agriculture take place in Crete?

- How have agricultural practices been changing over time and space?

- How important is agriculture to the Cretan economy and to Cretan rural life and identity?

- How sustainable is agriculture in Crete?

Spaces of Tourism

- Where are the tourist sites in Crete, who visits them, who do they cater for and why?

- How are different tourist sites constructed materially and imaginatively?

- What are the different tourist practices in rural Crete?

- How does tourism create tensions?

- What are the benefits and negative impacts of tourism in Crete?

- To what extent is tourism in Crete sustainable and how does this differ between different sites?

Migration and ldentity

- What are the impacts of different types of migration on rural Crete?

- Document different rural lives and activities

- How and why have rural identities, lives and spaces changed in Crete?

- What are the relationships between rural and urban areas?

There are specific marking criteria for video documentaries, which we would recommend you to consult. This should give you an idea of what we expect to see in the documentary and the standards needed to attain certain marks. We will take into account that most if not all of you will not have done something like this before when we mark these. We will, therefore, be keeping an open mind and are looking for a flow of the commentary and good visual images as well as signs of creativity and originality. Please ensure that you have thought about the video before we go so that you're not filming randomly. For example, you need to think about what/who you're representing and why as well as how you will go about doing this. The better you plan ahead, the less time you will have to invest into editing your film. 
When filming, you will have to strictly adhere to the following ethical code of conduct in order to guarantee your safety and the privacy of people you encounter during your fieldwork:

1. You must not film anywhere in the vicinity of military bases. This is very important because filming military facilities and planes is a very serious offence in Greece and you will be prosecuted by police. There is a military base next to the airport in Heraklion so you must not use the video at the airport or anywhere near the airport, even whilst on the coach.

2. You must not film people whose faces will be clearly visible without their permission. Therefore, if you want to film someone whose face will be clearly visible, you need to get them to sign an informed consent sheet (which we will distribute to you). The informed consent form will highlight what you are doing and why, and it will outline what will be done with the data collected.

You may film people whilst in the field, but any whose faces are clearly visible (and whose permission you haven't got) must be blurred during the film editing process. You will be shown how to do this.

If you happen to film children or vulnerable populations such as the homeless, their faces MUST be blurred in the final film. Please avoid filming vulnerable groups if at all possible.

Therefore, you must NOT show the faces and voices of people you have filmed without them signing an informed consent form.

If you would like to speak to someone, please approach them first to ask if they would mind being filmed and to get them to sign the informed consent form, which will also be translated into Greek. You will be given this.

You must be willing to provide participants with the option of viewing the finished documentary if they wish, so that they have the chance to comment on how they have been represented. In other words, if they ask to see the finished product, you have to be willing to send them a copy of it (Liz will do this for you).

Therefore, you will need to think carefully about how people are represented. Remember the power that you have in doing this. You must be sensitive to those you are portraying and ensure that you are acting ethically at all times, during and after filming, whilst in production and editing of the documentary.

3. You must not film people who are clearly and visibly uncomfortable with you filming them. Please be aware of this at all times whilst filming. If someone does not want you to film them you have to respect their wishes. Be aware of the ethical implications of a group of people descending upon one person with a video camera. This can be intimidating for some people, especially if English is not their first language.

4. Please do not trespass on private land whilst filming. If you are not sure about this or cannot read signs that are in Greek please ask Liz Mavroudi to translate. If there are no clear signs that the land is private, then it is ok to film provided you are discrete and do not damage anything. If, for example, there is clearly a fence, of which parts have been broken or fallen into disrepair, please do not attempt to access such land.

5. Be aware of cultural differences. You can speak to people in English but be aware that for most people you will be speaking to this is not their first language. You can ask Liz Mavroudi to translate if they speak no English at all, or if they do try to speak English to you (as many will) please be respectful of the fact that they are not speaking their first language. Remember that you are in Greece and that customs in rural areas in particular may be different to those you are used to. 


\section{Figure 4 Selected marking criteria for video presentations (13 marks out of 20)}

The overall criteria used to arrive at the mark reflect the ability of students to:

1. structure a video presentation

2. compile and video-edit suitable and relevant material

3. communicate effectively

4. deliver a balanced, original and complete presentation within a time limit

5. design and use visual material in creative and informative ways

6. undertake independent study of the topic in question

7. use effective audio material within presentation

The length of the presentation must conform to that prescribed by the module tutor.

\begin{tabular}{|c|c|c|}
\hline & 83 & $\begin{array}{l}\text { Excellent presentation scoring highly on each of the } 7 \text { criteria. Substantial knowledge and } \\
\text { critical understanding of material. Confident production of video, good illustrative material, } \\
\text { balanced and keeps to time. }\end{array}$ \\
\hline & 73 & $\begin{array}{l}\text { Very good presentation, balanced and keeps to time. Confident delivery of suitable well- } \\
\text { researched, and original material, and some evidence of critical thinking; edited images and } \\
\text { audio used are relevant. May lack the polish and fluency of a higher scoring presentation. }\end{array}$ \\
\hline \multirow{3}{*}{$\begin{array}{l}60- \\
69\end{array}$} & 68 & $\begin{array}{l}\text { A good presentation with a clear logical structure, coverage of well-researched, suitable } \\
\text { material and good visual material. }\end{array}$ \\
\hline & 65 & $\begin{array}{l}\text { A good presentation, well-structured and delivering appropriate, researched material. Some } \\
\text { minor shortcomings may include time keeping issues and a slight lack of clarity. }\end{array}$ \\
\hline & 62 & $\begin{array}{l}\text { A competent presentation delivering appropriate, fairly well researched material. Scores well on } \\
\text { the majority of criteria } 1-7 \text {. Shortcomings may include slightly imbalanced structure, some time- } \\
\text { keeping difficulties, inconsistent quality of visual and audio material. }\end{array}$ \\
\hline $\begin{array}{l}50- \\
59\end{array}$ & 58 & $\begin{array}{l}\text { A decent presentation demonstrating a reasonable standard in all aspects of the presentation. } \\
\text { Content is largely relevant and shows some evidence of research. Some ideas may be less } \\
\text { well expressed, editing, visual and audio aids may be ineffective at times. }\end{array}$ \\
\hline \multirow{2}{*}{$\begin{array}{l}50- \\
59\end{array}$} & 55 & $\begin{array}{l}\text { Presentation addresses most of the criteria } 1-7 \text {, content is fairly relevant but may be variable in } \\
\text { quality. The presentation may not be completed within the time limit or may be significantly } \\
\text { unbalanced. Visual and audio aids may be variable in quality and relevance. }\end{array}$ \\
\hline & 52 & $\begin{array}{l}\text { Adequate presentation but under performs on one or more key criteria such as relevance and } \\
\text { communication. Delivery may lack confidence, inability to hold the audience's attention through } \\
\text { the presentation. }\end{array}$ \\
\hline \multirow{2}{*}{$\begin{array}{l}40- \\
49\end{array}$} & 47 & $\begin{array}{l}\text { Weak but acceptable presentation. Some irrelevant or inaccurate material is included. May be } \\
\text { significantly under or over the time limit. Visual and audio material largely ineffective. }\end{array}$ \\
\hline & 43 & $\begin{array}{l}\text { Poor presentation with flaws in some aspects. May include a significant amount of irrelevant } \\
\text { material. Presentation lacks structure and does not communicate content to the audience. } \\
\text { Visual material is poorly edited, not always relevant; audio unclear and difficult to hear. }\end{array}$ \\
\hline \multicolumn{3}{|r|}{ Fail } \\
\hline $\begin{array}{l}30- \\
39\end{array}$ & 37 & $\begin{array}{l}\text { Presentation narrowly, but clearly, fails in several aspects. There may be major gaps in } \\
\text { knowledge, content and understanding and/or inclusion of substantial amounts of irrelevant } \\
\text { material. May be substantially under or over the time limit. }\end{array}$ \\
\hline $\begin{array}{l}20- \\
29\end{array}$ & 25 & $\begin{array}{l}\text { Presentation fails on most criteria. Very limited material, doesn't hold attention of audience. } \\
\text { Sections may be inaudible, the majority of visual aids are irrelevant or inappropriate. }\end{array}$ \\
\hline 0 & 0 & $\mathrm{mpt}$, or not ready to present by advertised deadline. \\
\hline
\end{tabular}

